Драгана В. Станковић Универзитет у Нишу

Педагошки факултет у Врању

Катедра за језике и књижевност
УДК: 811.163.41’366.54:373.21

https://doi.org/10.18485/uzdanica.2020.17.2.4

Оригинални научни рад

Примљен: 31. август 2020.

Прихваћен: 21. децембар 2020.

\title{
УПОТРЕБА ПАДЕЖА У ГОВОРУ ДЕЦЕ ПРЕДШКОЛСКОГ И ОСНОВНОШКОЛСКОГ УЗРАСТА ИЗ ВРАҢА - СОЦИОЛИНГВИСТИЧКИ ПРИСТУП ${ }^{1}$
}

$A \bar{u} c \bar{u} р а \kappa \bar{u}:$ У условима језичког аналитизма, најмлађи говорници призренско-тимочке говорне зоне имају великих проблема у усвајању стандарднојезичког падежног система. У складу с тим, предмет овог рада јесте употреба падежних облика у говору деце предшколског и основношколског узраста из Врања. Циљ рада јесте да се утврди које падежне облике користе деца за изражавање функција зависних падежа и колико је њихова употреба условљена не езичким чиниоцима. У прилог постављеном циљу најпре су утврђени сви падежни облици које деца користе, а затим и фреквентност употребе општег падежа у функцији зависних падежа и њена условљеност нејезичким чиниоцима израчунавањем индекса фреквенције, у складу са методологијом актуелних социолингвистичких истраживања. Добијени резултати указују на употребу трију падежних форми: општег падежа, стандарднојезичког падежног облика и хиперкорективног облика. Притом, општи падеж је најдоминантнија падежна форма, а његова употреба у мањој мери зависи од нејезичких чинилаца. Спроведено истраживање значајно је за наставу падежа на призренско-тимочком говорном подручју - указује на говорне навике деце у употреби падежа, што би требало имати у виду при реализацији наставе падежа српског језика.

Кључне речи: говор деце, падежни аналитизам, општи падеж, стандарднојезички падежни облици, нејезички чиниоци.

\section{УВОД}

Усвајање стандардног језика за говорнике призренско-тимочког говорног подручја јесте, како је једном приликом истакао П. Ивић, мучан процес који се не може извршити у потпуности (Тома 1998: 11). Захваћени интен-

${ }^{1}$ У раду су представљени резултати једног дела истраживања, спроведеног за потребе израде докторске дисертације под називом Говор вранске gеце йреgшколско̄̄ и школскоі уз-

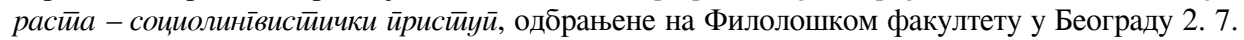
2018. године. 
зивним балканистичким процесима, у чијој је основи радикално развијање аналитичке структуре, говори ове зоне у знатној мери су упростили своју језичку структуру и на тај начин се, поред осталог, удаљили од осталих српских говора и стандардног језика. Структуралне разлике видљиве су на свим језичким нивоима.

Услед деловања балканистичких процеса, деклинациони систем призренско-тимочких говора претрпео је крупно преструктурирање синтетичког модела у аналитички. Функцију свих зависних падежа преузео је један падежни облик, тзв. општи падеж, облички једнак акузативу, у предлошкој конструкцији у којој се падежно значење преноси на предлог. Аналитизам у деклинацији именица забележен је у свим говорима призренско-тимочке дијалекатске области и показује велику стабилност (Станковић 2020). Зато је говорницима ове говорне зоне веома тешко да употребљавају стандарднојезичке падежне облике, да са аналитичког пређу на синтетички, флексијски падежни систем. П. Л. Тома разлог томе налази у сложености језичког система: „што су језичке јединице више интегрисане у језички систем, то све више зависе од систематске варијације и све су теже за усвајање од стране говорника неког другог лингвистичког система. Лакше је заменити један облик неким другим (нпр. лексему али и морфему као у случају замењивања аналитичког компаратива синтетичким компаративом), него усвојити синтаксички систем падежа (кад један једини облик општег падежа мора бити замењен стд. акузативом, генитивом, дативом, инструменталом или локативом...)” (Тома 1998: 439).

Досадашња истраживања показала су да најмлађа популација, при усвајању стандарднојезичке норме, има великих проблема у усвајању стандарднојезичког падежног система. Наставом падежа у школама на призренско-тимочком говорном подручју посебно се бавила М. Јањић (2004, 2005а, 2005б, 2005в, 2009). Општи закључак који произлази из њеног истраживања јесте да ученици на овом говорном подручју никада у потпуности не савладају падежни систем српског стандардног језика. Спроведено истраживање у двема основним школама у Врању (анализа 120 усмених и писмених вежби ученика првог, четвртог и свих старијих разреда) показало је да ученици у великој мери праве падежне грешке, при чему се највећи број њих односи на погрешну употребу акузатива и локатива у функцији прилошке одредбе за место (Јањић 2005а: 629-630). Посебно су занимљиви ставови према настави падежа које су просветни радници изнели у оквиру рада секције насловљене

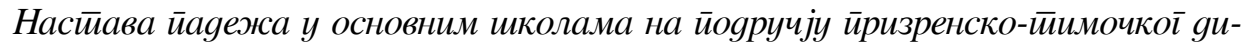
јалекй $а$ (Јањић 2005б). Наиме, сви учесници секције сматрају да се утицај локалног говора негативно одражава на наставу падежа и целокупну наставу граматике српског језика (Јањић 2005б: 138). Неки су чак наставу граматике сликовито упоредили с борбом против ветрењача: „Решења за овај проблем у настави ја немам, јер је покушај да деца причају књижевним језиком налик на борбу против ветрењача" (Јањић 2005б: 139). Цитираћемо још само 
једно искуство учесника семинара: „Већина деце заврши основну школу, а да не направи разлику између датива и локатива. Теоријски то савладају, али у пракси не примењују [...]” (Јањић 2005б: 140).

Нимало бољу ситуацију не налазимо ни када је у питању високошколско образовање. Р. Жугић је на материјалу од 58 писаних задатака студената једне високошколске институције на призренско-тимочком говорном подручју утврдила чак знатно већи број и различитије типове падежних грешака у поређењу са грешкама до којих је дошла М. Јањић у анализи употребе падежа у вишим разредима основношколског образовања (2012: 268-270, 2013). Падежне грешке тичу се употребе аналитичке предлошке конструкције са општим падежом у функцији стандарднојезичког падежног облика и употребе неодговарајућег падежног облика из стандардног језика, при чему су утврђена разна нестандардна мешања и комбиновања падежних облика.

Предмет нашег истраживања јесте употреба падежних облика у говору најмлађих Врањанаца, деце предшколског и основношколског узраста, од 5 до 14 година старости. Истраживања су показала да дете усваја падежне облике врло рано и пре многих других граматичких категорија - негде око треће године (Јоцић 2006: 111-130, Костић-Владисављевић 2008: 133-139). У складу с тим, наши испитаници поседују одговарајућу језичку компетенцију, у њиховој говорној активности јављају се различити падежни облици, који су предмет наше анализе.

\section{МЕТОДОЛОГИЈА ИСТРАЖИВАҢА}

Имајући у виду аналитизам који је у основи именичке деклинације говора призренско-тимочке зоне и продор флективне падежне форме под утицајем стандардног језика, којима је говор деце изложен, циљ рада јесте да се утврди које падежне облике користе деце предшколског и основношколског узраста за изражавање функција зависних падежа и колико је њихова употреба условљена нејезичким чиниоцима.

Ради остварења циља, постављена су три истраживачка задатка.

1. Утврдити све падежне облике које деца предшколског и основношколског узраста користе.

2. Утврдити фреквентност употребе дијалекатских облика падежа (тзв. општег падежа).

3. Утврдити условљеност употребе општег падежа следећим нејезичким чиниоцима: узрастом, полом, образовањем родитеља, местом становања, похађањем вртића/школе.

У складу с постављеним циљем, истраживање је спроведено према принципима актуелних социолингвистичких истраживања и урбане дијалек- 
тологије (више о томе у: Станковић 2018). Анализиран је говор 40 испитаника узраста од 5 до 14 година, различитог пола, места становања (центар / периферија града), образовања родитеља, похађања вртића/школе 2 К Како је предмет испитивања урбани говор, испитаници су деца која су рођена и живе у Врању и чији су родитељи рођени и живе у Врању. Према узрасту, испитаници су разврстани у три групе - деца предшколског узраста (16 испитаника), школског узраста од првог до четвртог разреда (12 испитаника) и школског узраста од петог до осмог разреда (12 испитаника). У оквиру предшколског узраста једну групу чине деца која иду у вртић (12 испитаника), а другу деца која не иду у вртић (4 испитаника). Девојчица је 20, а исто толико и дечака. Према месту становања, једну групу чине деца која живе у центру града (20 испитаника), а другу групу деца која живе на периферији (20 испитаника). Према образовању родитеља, једну групу чине деца чија су оба родитеља с високим (вишим) образовањем (12 испитаника), другу деца чији је један родитељ с високим (вишим) образовањем а други са средњим (13 испитаника) и трећу деца чија су оба родитеља са средњим образовањем (15 испитаника).

Грађа је прикупљена техником спонтаног разговора, који је испитивач водио са испитаницима ${ }^{3}$. Како би се испитаници у што већој мери служили свакодневним, неформалним говором, вођен је разговор о различитим темама које су им блиске. Испитивач се трудио да оствари што већу непосредност и да с њима разговара на дијалекту. Испитивач започиње разговор, предлаже теме, али дозвољава испитанику да говори и о другим темама које га интересују. Поред тога, испитаници су одговарали на директно постављена питања, уколико неки битан детаљ није добијен у спонтаном разговору, и описивали цртеже с посебним инструкцијама испитивача у виду питања којима се добија тражена језичка особина. Разговор је сниман диктафоном и транскрибован. Снимљени разговори трају од једног до два сата са сваким испитаником, тј. два школска часа с децом школског узраста. Тако је добијена грађа од око 70 сати аудио-снимака. У транскрибованом материјалу издвојене су и анализиране све падежне форме.

Фреквентност дијалекатских падежних облика утврђена је израчунавањем индекса фреквенције (ИФ), који се добија тако што се број забележених

${ }^{2}$ Социолингвистичка истраживања су показала да су наведени нејезички чиниоци релевантни за језичко понашање деце (Рајић 2009: 39). Такође, Љ. Рајић истиче да је оптимални број испитаника у социолингвистичким истраживањима између 25 и 90 (Исто). Ми смо се у спроведеном истраживању држали овог оптималног броја.

${ }^{3}$ Како су у средишту социолингвистички оријентисаних истраживања варијације језичких појава, спонтани говорни дискурс постаје значајан извор грађе. Ипак, треба имати у виду да неструктурирани интервју може да доведе до импровизације и сугестивности испитивача, нарочито зато што се одвија на дијалекту, па би могао утицати на испитанике онда када се двоуме између дијалекатских и стандарднојезичких облика. 
дијалекатских облика најпре подели са збиром дијалекатских и стандарднојезичких облика, а затим помножи са $100^{4}$ :

$$
\text { ИФ }=\frac{\text { дијалекатски облици }}{\text { дијалекатски и стандарднојезички облици }} \cdot 100
$$

На основу добијене вредности индекса фреквенције закључује се о употреби дијалекатског падежног облика - виши ИФ указује на учесталију употребу дијалекатског облика. Добијени резултати тумаче се методом дескриптивне анализе и приказују помоћу графикона и табеле уз коментар.

\section{АНАЛИЗА И ИНТЕРПРЕТАЦИЈА РЕЗУЛТАТА}

У ексцерпираном материјалу забележене су три форме падежа: дијалекатска форма - употреба општег падежа у функцији свих зависних падежа, стандарднојезичка форма која продире у аналитички систем под утицајем стандардног језика и различите нестандардне и хиперкорективне форме настале у покушају испитаника да дијалекатску форму замени стандарднојезичком.

Појава обличког колебања - наизменичне употребе општег падежа (a) и стандарднојезичког падежног облика (б), видљива је у изражавању свих падежних функција. Наводимо део грађе $\mathrm{e}^{5}$.

Функција генитива:

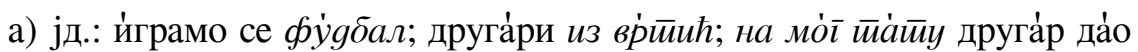

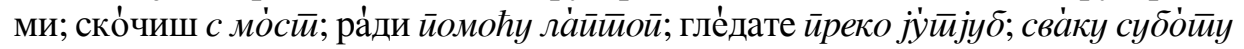

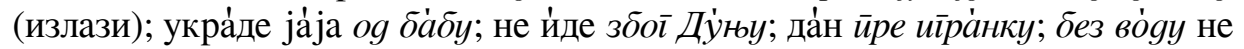
мо́жемо; свађа́ли се око на́слеgсйво;

мн.: пошто не́ма мно́го gеча́ци; е́во йоклони; о́ни ра́див у фа́брику ци -

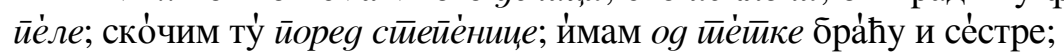

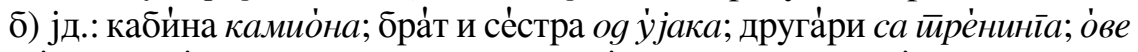

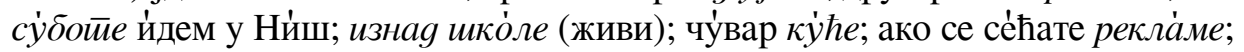

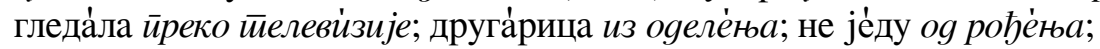

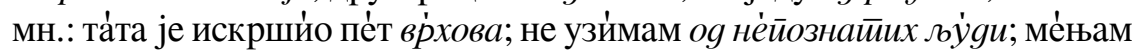
го́вор због̆ на́ $\overline{\text { } а в н и к а ; ~ м а ́ м а ~ и ~ ј а ́ ~ с м о ~ с е ~ п р е п и ́ р а л е ~ о к о ~ х а ́ љ и н а ; ~ п р о ́ ш л о ~ ј е ~}$ не́колико ї́guна; кра́љ а́јкула; са́мо у о́блику звgе́зgица и кружића.

${ }^{4}$ У проучавању урбаних идиома ову формулу примењује Д. Јутронић-Тихомировић (1986, 1988-1989), а затим и Ж. Бошњаковић (2009).

${ }^{5}$ У наведеним примерима све речи су акцентоване тако што се експираторни акценат, својствен анализираном говору, бележи знаком ', утврђеним у дијалектолошкој литератури, а одговарајући падежни облици истичу се италиком. 
Функција датива:

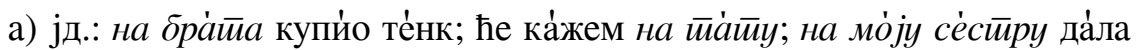
поква̀рен со́к; кад су на Лирију одсе́кли ро́г; предава́ла на ње́но оgеле́ъе; já не да́јем ни на јеgно́ géūe;

мн.: да пока́жем на gруїари и на gруїарице; да се пофа́лим на póguйељи; са́мо ка́же на gевојчице;

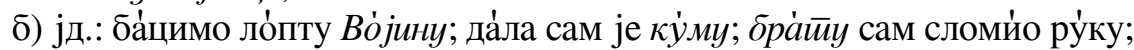

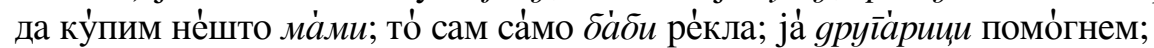

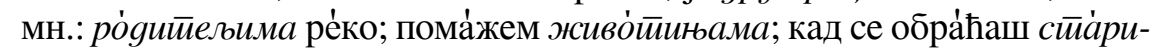
јим о́собама.

Функција акузатива ${ }^{6}$ :

а) спре́мају кола́чu; пу́цам у gруі̄u авијо̀ни; ми́ нави́јамо за gеча́ци; попе́о се ми́ш на ли́стиови; у сви́ іра́gови и́де; а то ӣpeg йзбори су прича́ли; на ирвви ви́ше (пецају); цр́тамо кружићћи; ће ми тре́ба два́ папи́ра за йра́сићu;

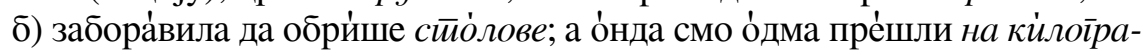

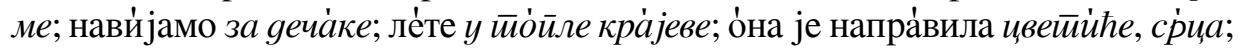
у̀век ми напра́ви gyїмёй

Функција инструментала:

a) јд.: путова́ли $c$ во́з; упа́ла у во́ду за Ка́рӣера; у'шо са со́к; ова́ко гу

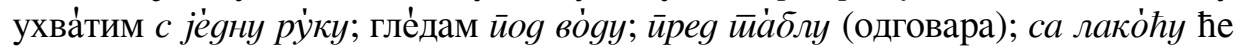
гу заврышим; се́дим $c \delta \dot{a} \delta y$;

мн.: што се тѐпав с ма́чеви; и о́на йpeg све́ gево́јчице (рекла); да те про-

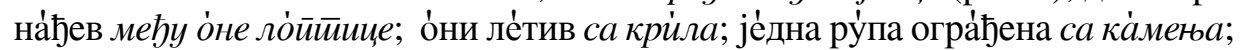
ра́ди с ве́лики gе́ца;

б) јд.: са gруїом сам во́зила ро́лере; и́ду са фбе́нером; и́дем йройоа́ром;

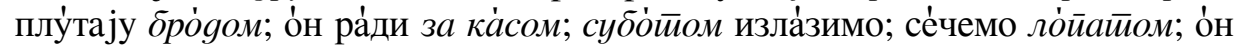
ра́ди са маллом gе́цом;

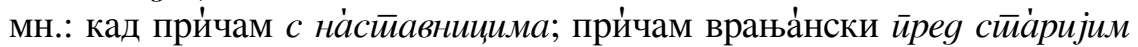

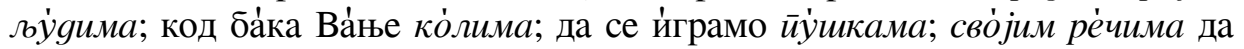
препйшемо пе́смицу.

${ }^{6}$ Разлика између облика општег падежа и акузатива видљива је код именица мушког и средњег рода множине, док се у облику једнине свих именица општи падеж поклапа са стандарднојезичким обликом акузатива. Из тог разлога дати су и разматрани само примери мушког и средњег рода множине. 
Функција локатива:

а) јд.: ту́ йо це́нйар изла́зим; на Се́верни ӣóл и́ма ле́д; на клави́р сви́ра;

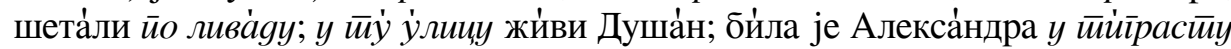

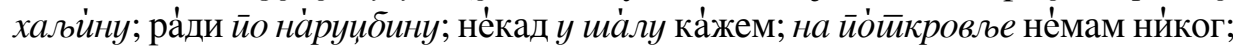
у кориі̄о г га пе́ремо;

мн.: приччамо о ма́скембали; виде́о сам у фйлмови; йдев са́мо йо кра́јеви; за́бавно је на ча́сови; у кафйћи сла́вимо; се́дели смо на клу̀йе; во́зив се $y$ колици; хо́да на йочкйћн;

б) јд.: ра́дила је у врӣìћy; пошто мно́го при́чамо на ча́cy; се́део $н а$

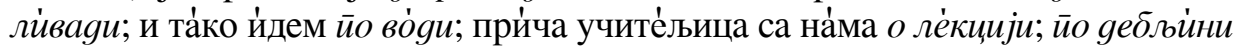

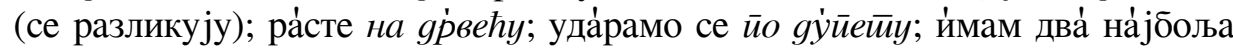
деча́ка у оgеле́ну;

мн.: да се вра́ти за че́трнес са́ти $у$ ко́лима хи́тне по́моћи.

Без обзира на продор флективне форме у све падежне функције, аналитичка конструкција $\bar{u} p e g л o \bar{\imath}+$ oйuйu йageж показује велику експанзију.

Ширећи своје поље употребе, аналитичка конструкција потискује беспредлошку падежну форму:

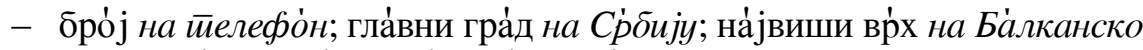
йолуостирво; у дру́ге држа́ве мно́го до́бар до́м на фйлмови;

- og мó̄ gégy рођѐн бра́т; а og ма́мy ро́дитељи жи́вив у Вра́њску Ба́њу;

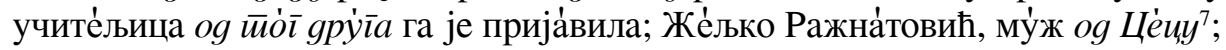

- пла́шим се og висину; зато́j се и одре́кла og имáне; ја̀ сам ослобо́ђена $o g$

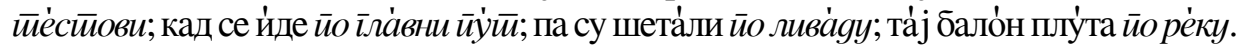

Многи предлози у аналитичкој конструкцији преузимају значења других предлога и употребљавају се уместо њих:

- предлог og у локативним конструкцијама, најчешће с глаголима говорења и мишљења, уместо предлога $о$ : приччао сам ти ју́че og Џони Те́cū;

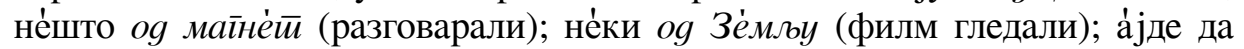
при́чамо og сий́ри фйлмови;

- предлог $o g$ с аблативним значењем уместо предлога $c$ : јёдна дру-

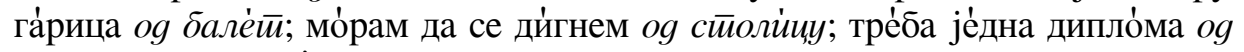
не́ко йінкмичење; о́дсуствујем оg ча́сови;

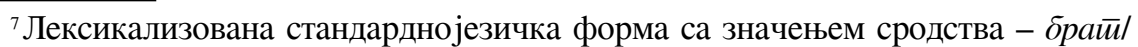

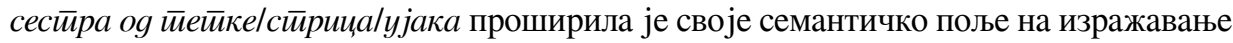
и других родбинских и социјалних односа. 
- предлог за са значењем узрока уместо предлога око: о́бично се сва́ђамо за рачуна́р; с то́м мла́ђом се р́вем за комйjy்йер; сва́ђају се за мими 8 ;

- предлог за у локативним конструкцијама, најчешће уз глаголе говорења и мишљења, уместо предлога $o^{9}$ : нйсам ти исприча́о за й்́̀ ло́йова;

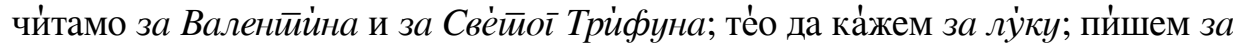
цвёће, за живо́̄̄ине; прича́ли за йра́ва де́тета;

- предлог на у значењу штете уз глаголе узимайи, узейи уместо предлога og: и у́зеде на Але́ксу; по̀сле сам узе́ла на ма́му па́ре; узи́мам на се́cūpe (ужину); узймам на се́стире со́бу;

- предлог збоі са значењем циља уместо предлога $p a g u^{10}$ : у Ми́нхен

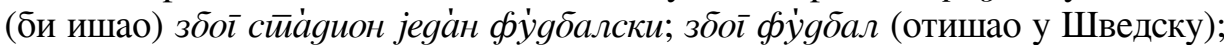
треб́á је та́мо да се́ди око три́ го́дине збо̄̄ йайùpu.

У једном броју примера забележили смо мешање предлога $у$ и на:

- y је́gну сли́ку је пока́зано; у йрафйку (се купују); у не́ко іродбље за љубймци га сахрани́ли;

- на gруі̄y рече́ницу је ве́лико сло́во; на Та́ковску у̇лицу (живи); вида́о сам на йірицу; гле́дам све́ на но́вине ла́птопови.

ми. Такве су:

Неке падежне конструкције употребљене су само у дијалекатској фор-

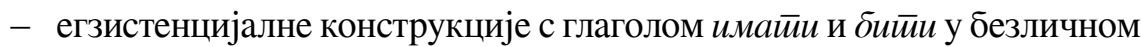
и личном глаголском облику презента, перфекта, потенцијала и футура и именичком јединицом у облику номинатива (да и́ма $c \bar{u} о \dot{л о в и ~ п о ~ ц е ́ о ~ с т а ́ н ; ~ у ~}$ шко́лу немма иіра́чке; има́ло оволике фо́ке; у На́ше де́те је бйло ма́скембал; бйће йромоција; има́о је базе́н; ни́су има́ле лойа̇̄uце; има́ли су др́ва; ста́лно је йуца́нье бйло);

- адвербијализовани дативни облик кући који је потиснуо адвербијализован израз $\operatorname{kog}$ куће у значењу места на коме се врши радња (имам и

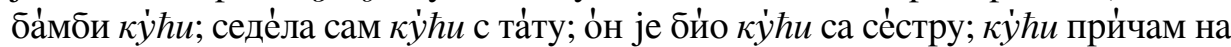
врања́нски; о́на је ове́ го́дине слави́ла ку่ћu).

\footnotetext{
${ }^{8}$ Предлог з $а$ са узрочним значењем бележи и М. Јуришић (2014: 482) у пчињском говору. У стандардном српском језику у генитивној узрочној конструкцији са узајамно-повратним

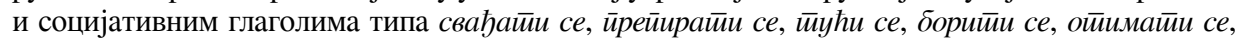

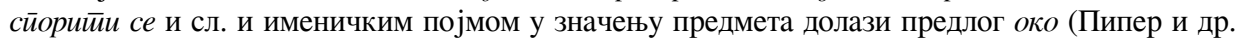
2005: 168).

${ }^{9}$ П. Радић (2003: 132-133) указује на „појачан удео предлошко-падежне конструкције за + акузатив, којом се неутралише синтетички модел у разговорном језику. Употреба предлога за уместо предлога $o$ у конструкцијама овог типа својствена је и македонском језику (Марков 1953: 194).

${ }^{10}$ Ову појаву бележи и М. Јуришић у говору Горње Пчиње (2014: 481), а својствена је и косовско-ресавским говорима (Јовић 1968: 165, Милорадовић 2003: 124-125). Више о овој појави у Јуришић 2015.
} 
На другој страни, у ексцерпираној грађи нису потврђени облици партитивног беспредлошког генитива у функцији допуне неких придева: вреgан, достиојан, свестиан, йлаgан, жеgан, жељан, жуяан (Стевановић 1969: 192, Фелешко 1995: 69), осим у два примера с придевом йун: дво́риште пу̀но c иіра́чке (И10), тёнк пу̀н $c$ љы่̀gu, затим партитивног генитива у функцији правог објекта (само у једном примеру бележимо конструкцију преузету из стандардног језика (ако и́маш хра́брост̄u да их пйпнеш)); у конструкцији

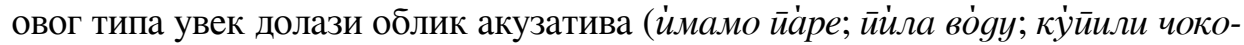
лágy) и словенског генитива (осим у неким устаљеним изразима, као што су: не́мам йојма, не́мам вре́мена, нёће и́мати вре́мена).

У покушају да дијалекатски облик замене стандарднојезичким ${ }^{11}$, а услед „језичке несигурности” (Тома 1998: 433), настају разноврсне хиперкорективне падежне форме ${ }^{12}$. Ове форме настају различитим језичким механизмима у чијој је основи укрштање дијалекатског и стандарднојезичког

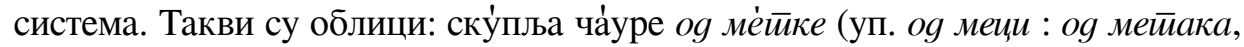

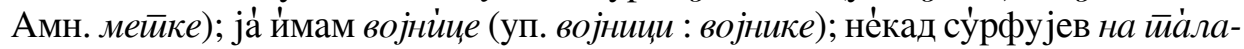

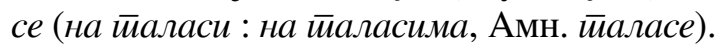

Несигурност у употреби постоји када су у питању бројне конструкције

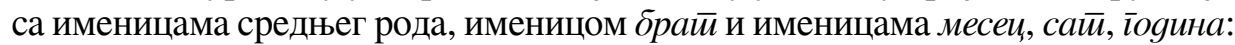

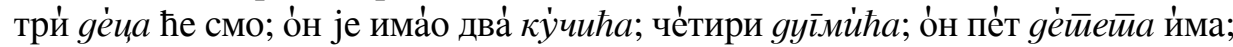

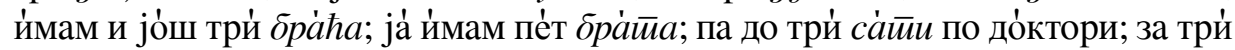
месе́ци; пре пѐт ме́сеца (почео да тренира); чѐтри їоgина.

Да постоји несигурност у употреби предлога $c(a)$, показују примери:

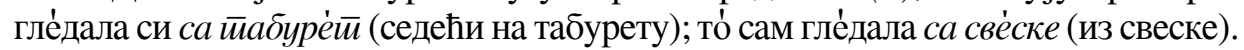

Многе нестандардне форме настају када у аналитичку конструкцију продре стандарднојезичка падежна форма: ја́ се пла́шим og gýxова; на́ставни-

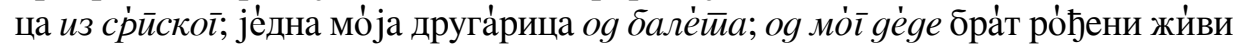
у Ни́ш; цр́там са хе́миском. Успостављање ових конструкција потпомогнуто је њиховом појавом у другим дијалектима и разговорном језику ${ }^{13}$.

\footnotetext{
${ }^{11}$ Овај смер укрштања могао би, у мањем проценту, бити и обрнут - деца знају стандарднојезички облик, али га желе заменити дијалекатским услед интеракције у којој доминира дијалекатски говор.

${ }^{12}$ У Енциклойеgијском речнику линївисиичиких назива термин хиперкорекција се дефинише на следећи начин: „pogrešan ili nepravilan izgovor ili oblik koji je rekonstruisan s namjerom da zamijeni jedno stanje, koje se smatra nepravilnim, stanjem koje se smatra pravilnim" (Simeon 1969: 475-476). У социолингвистичкој литератури за ову појаву се користи термин иниеерgијалекайски, који је први употребио П. Традџил за облике између два дијалекта, тј. између дијалекта и стандардног језика, сматрајући и стандардни језик врстом дијалекта (Чејмберс, Традџил 1980: 39).

${ }^{13}$ Тако нпр., ширење конструкције $c(a)+$ И у значењу инструментативности бележе дијалектолози у многим говорима (Ивић 1954: 227-228, Радић 2003: 135). Ову појаву М. Стевановић објашњава утицајем суседних западноевропских језика, првенствено италијанског и немачког (1984-1985: 738), док М. Ивић сматра да ова појава представља „природни даљи
} 
У неким примерима забележена је неутрализација граматичког односа између акузатива и локатива - употребљен је облик локатива уместо акузатива у значењу места завршетка кретања: уंшо је у сво́joj cóбu; о́нда су се йрeсе́лили у Вра́ньској Ба́ни; ја̇ сам и́шо у о́вој шко́ли; чове̇ка из мо́зга преба́цује y $\bar{u} \dot{e} л у$ Аватара; па је до́шла код јёдну друга́рицу у крйлу (уп. Јањић 2005а).

Стандарднојезички падежни облици најлакше продиру у анализирани говор у виду устаљених израза (не́ма ша̇нсе, не́мам йојма, из виђе́ља, ирреко ве́зе,

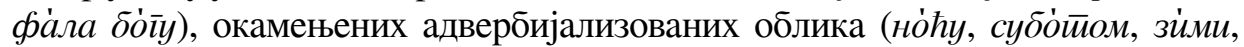
ре́gом; којјим слу́чајем, йоре́клом) и устаљених стандарднојезичких конструкција из различитих сфера друштвеног живота - у називима улица, установа, манифестација, празника, филмова, серија, емисија, књига, цртаних филмова, цртаних ликова, у устаљеним синтагматским спојевима као називима различитих појмова, у називима школских предмета, појмовима из школског живота

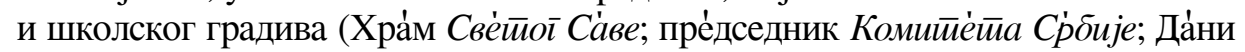

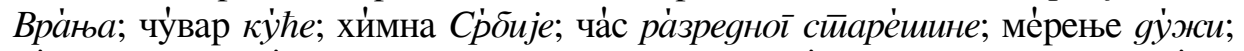
до́ба ра́не ју̀ре; дёлење ра́ционалних бројјева, Пингвйни са Маgайаскара, Сне́жа-

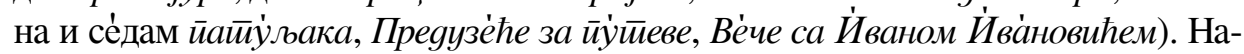
ведени облици представљају једну семантичку целину која доприноси очувању стандарднојезичке форме (више о томе у: Марковић 2014: 116).

У анализираном говору деце предшколског и основношколског узраста из Врања општи падеж употребљен је 5452 пута, а стандарднојезичка падежна форма 1145. Индекс фреквенције (ИФ) општег падежа у функцији зависних падежа износи 82,64 , на основу чега се може говорити о релативно стабилној аналитичкој деклинацији у говору наших испитаника и мањем утицају стандардног језика на падежни систем.

У графикону 1 дат је индекс фреквенције општег падежа у функцији сваког падежног облика појединачно.

Графикон 1. Индекс фреквенције општег падежа у функцији зависних падежа

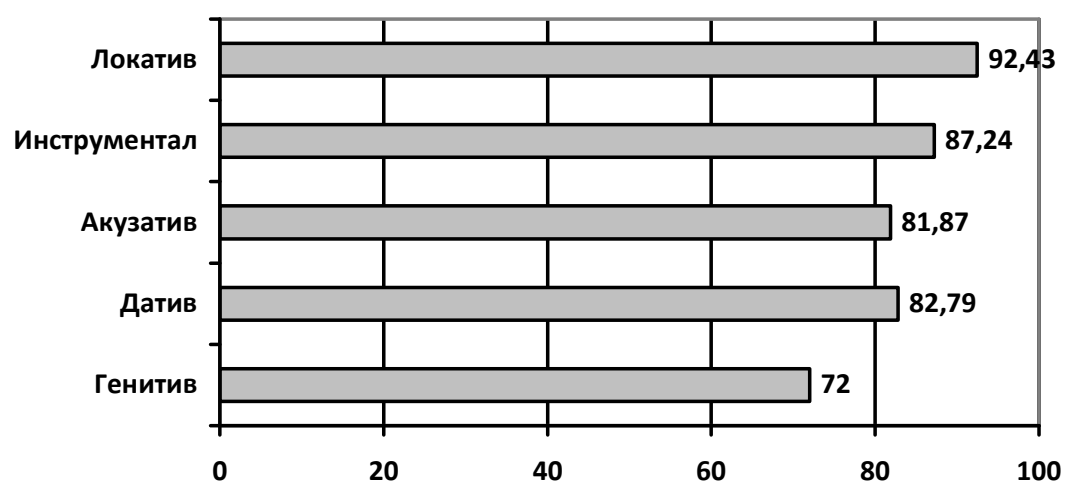

развој једног процеса који је у току већ од најстаријих епоха српскохрватског језика" и да је страни утицај само убрзао тај процес (1954: 231-232). 
Статистички подаци показују да испитаници чији је говор анализиран у највећој мери користе општи падеж у функцији локатива (ИФ 92,43), затим инструментала (ИФ 87,24), датива (ИФ 82,79) и акузатива (ИФ 81,87). Нешто већу изложеност утицају стандардног језика показује генитив (ИФ општег падежа износи 72).

Индекс фреквенције општег падежа у односу на узраст, пол, образовање родитеља, место становања, (не)похађање вртића и похађање вртића/ школе дат је у табели $1^{14}$.

Табела 1. Индекс фреквенције општег падежа у односу на нејезичке чиниоце

\begin{tabular}{|c|c|c|c|c|c|c|c|c|c|c|c|}
\hline \multicolumn{10}{|c|}{ HЕЈЕЗИЧКЕ ВАРИЈАБЛЕ } \\
\hline Узраст & ИФ & Пол & ИФ & $\begin{array}{c}\text { Образовање } \\
\text { родитеља }\end{array}$ & ИФ & $\begin{array}{c}\text { Место } \\
\text { становања }\end{array}$ & ИФ & Вртић & ИФ & $\begin{array}{c}\text { Вртић/ } \\
\text { школа }\end{array}$ & ИФ \\
\hline $\begin{array}{c}\text { пред- } \\
\text { школски }\end{array}$ & 89,24 & мушки & 85,91 & високо & 68,56 & центар & 79,31 & иде у вртић & 88,40 & иде у вртић & 88,40 \\
\hline $\begin{array}{c}\text { школски } \\
1-4\end{array}$ & 69 & женски & 79,05 & $\begin{array}{c}\text { високо/ } \\
\text { средње }\end{array}$ & 87,71 & периферија & 86,33 & $\begin{array}{c}\text { не иде } \\
\text { у вртић }\end{array}$ & 93,32 & иде у школу & 79,21 \\
\hline $\begin{array}{c}\text { школски } \\
5-8\end{array}$ & 88,47 & & & $\begin{array}{c}\text { средње } \\
90,14\end{array}$ & & & & & & \\
\hline
\end{tabular}

Статистички подаци показују различиту заступљеност општег падежа у функцији зависних падежа у односу на узраст, пол, образовање родитеља, место становања и (не)похађање вртића / школе у анализираном говору.

Нижу фреквенцију употребе општег падежа имају испитаници друге узрасне групе, деца од првог до четвртог разреда (ИФ 69). Остале две групе, предшколци (ИФ 89,24) и ученици старијих разреда (ИФ 88,47) имају виши и готово уједначен ИФ општег падежа.

Девојчице у нешто мањој мери користе општи падеж (ИФ 79,05) у односу на дечаке (ИФ 85,91).

Што је нижи степен образовања, фреквенција општег падежа се повећава - општи падеж је у највећој мери присутан у говору испитаника чија су оба родитеља са средњим образовањем (ИФ 90,14), а у најмањој у говору испитаника чија су оба родитеља с високим (вишим) образовањем (ИФ 68,56).

Испитаници из центра града нешто ређе користе општи падеж (ИФ 79,31) него испитаници с периферије (ИФ 86,33).

${ }^{14}$ Статистичка анализа није обухватила хиперкорективне падежне облике, као ни облике који представљају устаљене форме какви су устаљени изрази, називи улица, установа, манифестација, празника, филмова, серија, емисија, књига, цртаних филмова, цртаних ликова и сл. Такође, искључена је из анализе и аналитичка на-конструкција у посесивном значењу с обзиром на то да се на њеном месту у стандардном језику користи облик генитива, датива и

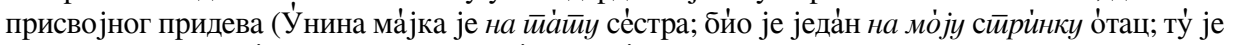
на мојје се́сйре шми́нкерница; што су ве́лике ши́шке на ову́ gевојчицу). 
Вртић нема значајнијег утицаја на употребу општег падежа у говору испитаника предшколског узраста - ИФ општег падежа у говору деце која похађају вртић износи 88,40, а деце која не похађају вртић 93,32.

Школа има нешто јачи утицај на употребу општег падежа у односу на вртић, што је очекивано, али опет недовољно - ИФ општег падежа у говору школске деце износи 79,21, а деце која иду у вртић 88,40.

Разлике у фреквенцији употребе општег падежа код свих нејезичких параметара постоје, али су мале, што говори о њиховом невеликом утицају на употребу општег падежа у анализираном говору деце. Нешто су израженије разлике када је у питању образовање родитеља - што је виши степен образовања родитеља, нижи је ИФ општег падежа. На другој страни, узраст показује ирелевантност - с узрастом се не смањује фреквентност употребе општег падежа. Говор друге узрасне групе, ученика млађих разреда, подложнији је утицају стандардног језика.

\section{ЗАКЉУЧАК}

За изражавање функција зависних падежа испитаници, деца предшколског и школског узраста из Врања, користе три падежне форме: општи падеж, најчешће у аналитичкој предлошкој конструкцији, затим стандарднојезички падежни облик и хиперкорективни облик. Притом је општи падеж најдоминатнија падежна форма, на основу чега се може говорити о постојаном падежном аналитизму у говору наших испитаника. У условима падежног аналитизма, аналитичка конструкција потискује беспредлошку падежну форму, а многи предлози шире своје поље употребе (og, за, нa, збо $\overrightarrow{)}$. На другој страни, флективна падежна форма, у мањој мери, продире у све падежне функције.

Стандарднојезички падежни облик најлакше се успоставља у оквиру устаљених форми као што су устаљени изрази, називи улица, установа, манифестација, празника, филмова, серија, емисија, књига, цртаних филмова, цртаних ликова и адвербијализованих облика. Из тог разлога устаљене форме представљају значајан говорни модел који треба систематски уводити у оквиру процеса усвајања стандардног језика. Већ на предшколском узрасту требало би их усвајати глобално, да би се на школском узрасту могло на њих рачунати пре уласка у граматичке анализе.

Појава хиперкорективних облика, насталих укрштањем двају система, дијалекатског и стандарднојезичког, указује на несигурност у употреби стандарднојезичких падежних форми (ску́пља ча́уре $о g$ ме́йке, че́тири gyїмйћa,

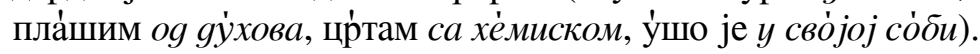

Утицају стандардног језика одолева егзистенцијална конструкција с

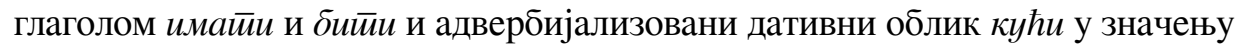


места вршења глаголске радње - потврђени су само у дијалекатском облику, док ниједном није употребљен облик партитивног генитива у функцији допуне придева и правог објекта, као ни облик словенског генитива.

Употреба општег падежа у функцији зависних падежа показује високу фреквенцију (ИФ 82,64). Притом, најстабилнији је у функцији локатива (ИФ $92,43)$, док је продор стандарднојезичког облика нешто већи када је у питању функција генитива (ИФ општег падежа у генитивној функцији износи 72).

Фреквенција употребе општег падежа у зависности од нејезичких параметара показује невелики утицај анализираних нејезичких чинилаца (узраста, пола, образовања родитеља, места становања, похађања вртића и школе) на употребу општег падежа. Нешто су израженије разлике када је у питању образовање родитеља - ИФ општег падежа у говору испитаника чија су оба родитеља са средњим образовањем износи 90,14, а у говору испитаника чија су оба родитеља са високим/вишим образовањем износи 68,56. На другој страни, узраст показује ирелевантност када је у питању употреба општег падежа - са узрастом се не смањује ИФ општег падежа - док је у говору предшколаца (ИФ 89,24) и ученика старијих разреда основне школе (ИФ 88,47) готово уједначен (ИФ 89), у говору ученика млађих разреда је знатно нижи (ИФ 69). Добијени резултат се може објаснити јачим деловањем школе и учитеља као ауторитета на овом узрасту, у складу са Пијажеовом теоријом развоја моралног расуђивања (више о томе у Миочиновић 2004: 19-26), што је у складу са развојним карактеристикама сваког узраста - деца старијег школског узраста релаксиранија су и мање подложна утицају са стране, за разлику од деце млађег школског узраста која (тек зашавши у образовни систем) развојно теже поштовању норме упркос утицајима (изван тог система). Предшколска деца пак уче по моделу и прате говорни модел у свакој конкретној говорној (ситуационој) интеракцији.

Описане говорне навике испитаника у употреби падежних облика указују на неопходност да се у настави граматике српског језика много више пажње посвети усвајању стандарднојезичког падежног система. Настава падежа захтева примену добро осмишљених облика рада, метода, наставних средстава, већи број часова обраде и увежбавања, као и већи број часова говорних вежби. Међутим, већ на предшколском узрасту неопходно је систематско увођење алтернатива за дијалекатске облике и конструкције. На тај начин ће се у дечјем језичком искуству градити потенцијали за усвајање стандардног језика на школском узрасту.

Како је аналитичка форма у функцији локатива врло стабилна, у обради деклинационог система највише пажње треба посветити овом падежу. Такође, посебан приступ захтевају и све оне падежне конструкције и облици који су у анализи показали већу отпорност на утицај стандардног језика. 
У раду је представљен један могући приступ анализи језичких облика у говору деце. С обзиром на то да је спроведено истраживање показало да у свом језичком искуству дете има потенцијално две могућности израза, у наредним истраживањима значајно би било испитати разлику између потенцијалних алтернатива за које се дете у говорној интеракцији опредељује и облика који у његовим језичким компетенцијама немају алтернативу (увек су дијалекатски). Такође, посебну пажњу завређује и питање говорног узора који за децу представљају васпитачи, учитељи и наставници српског језика - у којој мери њихов говор утиче на усвајање стандардног српског језика и колико је релевантан за језичко понашање деце.

\section{ЛИТЕРАТУРА}

Бошњаковић (2009): Ж. Бошњаковић, Однос стандардних и дијалекатских особина у говору ученика неких банатских основних школа, Научни састианак славистй у Вукове gане XXXVIII/1, Београд: Међународни славистички центар, 341-350.

Жугић (2012): Р. Жугић, Неке одлике писане језичке културе студената на призренско-тимочком дијалекатском подручју (на примерима синтаксе падежа и синтаксе реченице), Наме сииварање, 3-4, Лесковац: Лесковачки културни центар, 265-275.

Жугић (2013): Р. Жугић, Употреба падежа у писаном изражавању студената на

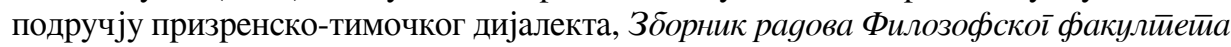
у Пришиеини, XLIII/2, Приштина: Филозофски факултет, 511-528.

Ивић (1954): М. Ивић, Значења сриискохрвайскої инсиирумениеала и њихов развој, Београд: САНУ.

Јањић (2004): М. Јањић, Настава падежа у основним школама призренско-тимочког дијалекта, Књижевност̄ и језик, LI/3-4, Београд: Друштво за српски језик и књижевност Србије, 407-425.

Јањић (2005a): М. Јањић, Неки проблеми у вези са наставним интерпретацијама акузатива и локатива у основним школама на дијалекатском подручју, Срйски језик, X/1-2, Београд: Филолошки факултет, 629-637.

Јањић (2005б): М. Јањић, Настава падежа у дијалекатској средини, Књижев-

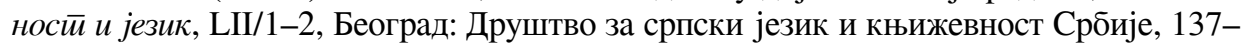
142.

Јањић (2005в): М. Јањић, Насйава йаgежа у йеорији и йракси, Врање: Учитељски факултет.

Јањић (2009): М. Јањић, Падежни систем на дијалекатском подручју, Дија-

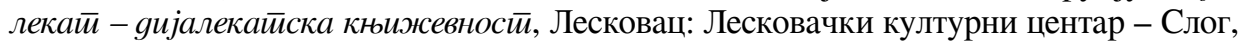
69-77.

Јовић (1968): Д. Јовић, Трстенички говор, Срйски яијалекӣолошки зборник, XVII, Београд: Институт за српски језик САНУ, 1-240.

Јоцић (2006): M. Jocić, Jezik, komunikacija, razvoj, Novi Sad: Dnevnik. 
Јуришић (2014): М. Јуришић, Синтакса падежа Горње Пчиње, Срйски gијалекйолошки зборник, LXI, Београд: Институт за српски језик САHУ, 373-533.

Јуришић (2015): М. Јуришић, Предлози збо̄ и раgи у српским народним говорима, Пуиеевима срйских ияиома: зборник у часии Раgивоју Млаgеновићу йовоgом 65. рођеняана, Крагујевац: Филолошко-уметнички факултет, 267-284.

Јутронић-Тихомировић (1986): D. Jutronić-Tihomirović, Morfološke promjene u splitskom vernakularu, Filologija, XIV, Zagreb: Hrvatska akademija znanosti i umjetnosti, 153-160.

Јутронић-Тихомировић (1988-1989): D. Jutronić-Tihomirović, Jezično prilagođavanje na sintaksičkom nivou, Radovi Filozofskog fakulteta u Zadru. Razdio filoloških znanosti, XVIII, Задар: Филозофски факултет, 51-59.

Костић, Владисављевић (2008): Đ. Kostić, S. Vladisavljević, Pojava padeža, $M e$ йоgика развоја іовора - изабрани иеексйови, Јагодина: Педагошки факултет, 133-139.

Марков (1953): Б. Марков, Предлогот за и неговите значења, Макеgонски јазик, IV/9, Скопље: Институт за македонски јазик „Крсте Мисирков”, 193-206.

Марковић (2014): J. Марковић, Окамењене падежне форме у призренско-

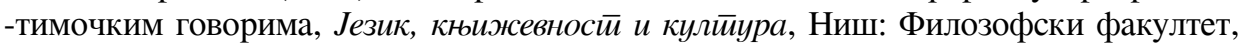
$115-123$.

Милорадовић (2003): С. Милорадовић, Уӣойреба йаgежних облика у іовору

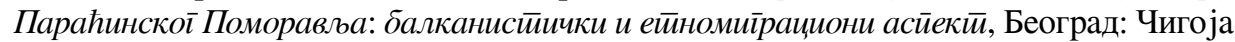
штампа.

Миочиновић (2004): Љ. Миочиновић, Морални развој и морално васйийање: коїнийивно-развојно схвайане, Београд: Институт за педагошка истраживања.

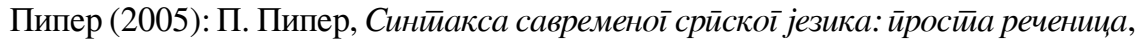
Београд: Институт за српски језик САНУ - Београдска књига; Нови Сад: Матица српска.

Радић (2003): П. Радић, О два аспекта балканизације српског књижевног језика, Јужнословенски филолой, LIX, Београд: Институт за српски језик САНУ, 105-152.

Рајић (2009): Љ. Рајић, Градски говори, Говор Новоі Саgа, св. 1: Фонейске особине, Нови Сад: Филозофски факултет, 31-45.

Симеон (1969): R. Simeon, Enciklopedijski rječnik lingvističkih naziva, Zagreb: Matica hrvatska.

Станковић (2018): D. Stanković, Speech of preschool children and elementary school students from Vranje from the standpoint of urban dialectology, Facta Universitatis, Series: Teaching, learning and teacher education, 2/1, Vranje: Pedagoški fakultet, 59-70.

Станковић (2020): Д. Станковић, О именичкој деклинацији у говорима при-

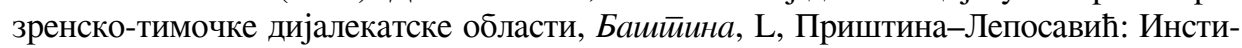
тут за српску културу, 57-72.

Стевановић (1984-1985): М. Стевановић, Социјатив - инструментал: једнакост и разлике, додири и мешања, Зборник Майице срйске за фбилолоіију и линївистиику, XXVII- XXVIII, Нови Сад: Матица српска, 733-740.

Стевановић (1969): М. Стевановић, Савремени срйскохрвайски језик II, Београд: Научна књига.

Тома (1998): П. Л. Тома, Говори Ниша и околних села, Београд: Институт за српски језик САНУ - Ниш: Просвета. 
Фелешко (1995): К. Фелешко, Значење и синйакса срӣскохрвайской иенийива, Београд: Орфелин - Вукова задужбина; Нови Сад: Матица српска.

Чејмберс, Традџил (1980): J. K. Chambers, P. Trudgill, Dialectology, Cambridge: Cambridge University Press.

\section{Dragana V. Stanković}

University of Niš

Faculty of Education in Vranje

Department of Languages and Literature

\section{USE OF CASES IN THE SPEECH OF PRESCHOOL AND PRIMARY SCHOOL CHILDREN FROM VRANJE - SOCIOLINGUISTIC APPROACH}

Summary: In the conditions of language analytism, the youngest speakers of the Prizren-Timok Serbian dialect have difficulties in adopting the standard language case system. In accordance with that, this paper deals with the use of case forms in the speech of preschool and primary school children from Vranje. The aim of the paper is to determine which case forms are used by children to express the case functions and whether their use is conditioned by non-linguistic factors. To begin with, the case forms used by children were identified, the frequency of using the general case in place of the dependent ones was determined, as well as the non-linguistic factors conditioning its use; the calculation was done using the frequency index, in accordance with the contemporary methodology of socio-linguistic studies. The research results indicate the use of three case forms - the general case, standard language case form and a hypercorrective form. At the same time, the general case is the most dominant case form, and its use depends to a lesser extent on non-linguistic factors. The conducted research is important for teaching cases of Serbian language in Prizren-Timok speaking area - it indicates children's speech habits regarding the use of cases, which should be kept in mind in language teaching.

Keywords: children's speech, case analytics, general case, standard language case forms, non-linguistic factors. 